\title{
Faktor-Faktor Yang Berhubungan Dengan Kinerja Perawat Dalam Penerapan Proses Keperawatan
}

\author{
Calita Elytisia Monica Ginting \\ calitaelytisia11@gmail.com
}

\section{Latar Belakang}

Kinerja merupakan suatu hasil kerja secara kualitas dan kuantitas yang dicapai oleh seorang perawat dalam melaksanakan tugasnya sesuai dengan tanggung jawab yang telah diberikan.Kinerja perawat adalah perilaku kerja yang ditampilkan oleh perawat dalam memberikan asuhan keperawatan kepada pasien,yang digambarkan dalam pelaksanaa rencana tindakan yang ditentukan dengan maksud memenuhi kebutuhan pasien secara maksimal. Kinerja perawat dalam melaksanakan asuhan keperawatan selalu menggunakan pendekatan proses keperawatan.Proses keperawatan adalah metode asuhan keperawatan yang digunakan perawat sebagai metode pemecahan masalah klien yang bersifat ilmiah dan merupakan serangkaian tindakan untuk mengkaji dan mengidentifikasi masalah kesehatan,menetapkan diagnosa keperawatan,merencanakan secara sistematis,melaksanakan tindakan keperawatan untuk membantu klien mencapai kesehatan yang optimal dan mengevaluasi hasil tindakan keperawatan (Ann Marriner).

Proses keperawatan harus diterapkan secara berurutan,terus menerus,saling berkaitan dan dinamis.Kinerja perawat dalam penerapan proses keperawatan sangat mempengaruhi kepuasan pasien,sehingga pelayanan asuhan keperawatan yang diberikan perawat kepada pasien harus bersifat professional agar membantu pasien untuk memulihkan dan meningkatkan kemampuannya dalam memenuhi kebutuhan hidupnya.Salah satu metode dalam menilai kinerja perawat yaitu dengan melihat standar asuhan keperawatan.Penilaian kinerja adalah sebagai alat yang dapat digunakan secara efektif untuk mengetahui kualitas dan kuantitas seorang perawat dalam memberikan pelayanan asuhan keperawatan.Perawat dapat menggunakan proses operasional kinerja untuk mengatur arah kerja dalam memilih,melatih,membimbing perencanaan,serta memberi penghargaan kepada perawat yang kompeten dapat memenuhi tingkat kepuasan pasien.Hal pertama yang dilakukan perawat dalam memberikan asuhan keperawatan ialah pengkajian untuk memperoleh data sesuai kondisi pasien. 
Kinerja perawat dipengaruhi oleh 3 faktor yaitu faktor individu,faktor psikologis dan faktor organisasi.Faktor individu meliputi kemampuan dan keahlian,latar belakang,dan demografi seseorang.Faktor psikologis meliputi persepsi,sikap,motivasi,kepribadian dan belajar.Faktor organisasi meliputi sumber daya,imbalan,beban kerja,struktur,supervisi,dan kepemimpinan.

Kata kunci : kinerja perawat,proses keperawatan,faktor yang mempengaruhi

\section{Metode}

Metode yang digunakan dalam kajian ini adalah membaca,memahami dan menganalisis beberapa sumber seperti buku referensi jurnal,buku teks,dan e-book yang berkaitan dengan faktor-faktor yang berhubungan dengan kinerja perawat dalam penerapan proses keperawatan.

Sebelum menerapkan metode tersebut,terlebih dahulu dilakukan pengumpulan data dan membandingkan beberapa sumber sesuai dengan topik.Kriteria dalam penelusuran beberapa sumber ialah dengan tahun paling tua 2012.Pada kajian ini juga akan ditambahkan referensi kunci yang telah ditentukan.Referensi kunci tersebut akan diletakkan pada bagian daftar pustaka.

\section{Hasil}

Berdasarkan pengumpulan data dan perbandingan beberapa sumber didapatkan bahwa kinerja perawat yang baik merupakan jembatan dalam menjawab jaminan kualitas pelayanan kesehatan yang diberikan terhadap pasien baik yang sakit maupun sehat.Kunci utama dalam peningkatan kualitas pelayanan kesehatan adalah perawat yang mempunyai kinerja tinggi.Perawat sebagai suatu profesi harus dapat mempertahankan dan meningkatkan mutu asuhan keperawatan dengan standar.Standar merupakan level kinerja yang diinginkan dan dapat dicapai dimana kerja aktual dapat dibandingkan.

Kinerja klinis perawat dipengaruhi oleh faktor internal dan faktor eksternal,faktor internal adalah keterampilan dan motivasi perawat,sedangkan faktor eksternal adalah supervisi,gaya kepemimpinan dan monitoring.Perawat diharapkan dapat menunjukkan kontribusi profesionalnya secara nyata dalam meningkatkan mutu keperawatan,yang berdampak terhadap pelayanan kesehatan secara umum pada organisasi tempatnya bekerja,dan dampak akhir bermuara pada kualitas hidup dan kesejahteraan masyarakat. 
Komponen kinerja perawat pelaksana menurut Ilyas (2012) meliputi hubungan dengan pasien,hubungan dengan rekan kerja,kemampuan professional,potensi untuk tumbuh dan kembang,sikap terhada rumah sakit dan kualifikasi personal.Menurut Schoessler (2008) perawat memiliki kinerja yang baik jika memenuhi tujuh komponen yaitu : sebagai penolong pasien,edukator dan pelatih bagi pasien,diagnostik dan memonitor pasien,administrasi dan monitor intervensi terapeutik,monitor dan menjamin kualitas asuhan,manajemen perubahan situasi darurat yang efektif,organisasi,dan kompetensi kerja.Maka dapa dikatakan bahwa komponen kinerja perawat merupakan gabungan dari fungsi perawat dalam memberikan asuhan keperawatan,hubungan interpersonal,tanggung jawab,ketaatan,dan kejujuran.

Dalam bidang keperawatan,kepemimpinan merupakan salah satu faktor penting.Faktor kepemimpinan dapat memberikan pengaruh yang berarti terhadap kinerja perawat karena pimpinan yang merencanakan, menginformasikan, membuat, dan mengevaluasi berbagai keputusan yang harus dilaksanakan dalam organisasi tersebut.Kepemimpinan dapat memotivasi perawat untuk bekerja dengan penuh semangat sehingga hasil yang ingin dicapai dapat memuaskan perawat maupun rumah sakit.

\section{Pembahasan}

Perawat merupakan suatu profesi yang bersifat kemanusiaan yang dilandasi rasa tanggung jawab dan pengabdian sehingga layanan perawat selalu menyangkut upaya kemanusiaan yang pelaksanaannya membutuhkan ketulusan,saling menghargai dan kebijaksanaan terhadap sesama manusia.Kinerja perawat merupakan penentu kepuasan pasien.Kinerja perawat dalam penerapan proses keperawatan merupakan aplikasi kemampuan atau pembelajaran yang diterima selama menyelesaikan program pendidikan keperawatan untuk memberikan pelayanan kesehatan secara langsung kepada pasien.Sehingga dalam penerapan proses keperawatan sangat perlu mengetahui faktor-faktor apa saja yang mempengaruhi kinerja agar perawat dapat meningkatkan kualitas pelayanan.Beberapa faktornya dapat dikemukakan sebagai berikut :

\section{Motivasi}

Motivasi merupakan dorongan yang berpengaruh membangkitkan,mengarahkan,dan memelihara perilaku yang berhubungan dengan lingkungan kerja.Motivasi kerja yang semakin tinggi menjadikan perawat mempunyai semangat yang tinggi untuk memberikan pelayanan yang terbaik. Faktor-faktor seperti kepuasan terhadap gaji dan insentif yang 
diterima,kedudukan dan kondisi lingkungan kerja yang kondusif akan mendorong tenaga perawat untuk bekerja lebih baik sehingga kinerjanya lebih baik pula.Motivasi terbentuk dari sikap seorang perawat dalam menghadapi situasi kerja.

\section{Supervisi}

Supervisi merupakan bagian penting dari manajemen keperawatan,karena dengan supervisi dapat mengatasi masalah dalam organisasi dengan cepat.Tugas supervise tidak bisa dipisahkan dari fungsi kepemimpinan.Supervisi yang dilakukan dengan benar merupakan bentuk dukungan dari lingkungan untuk meningkatkan kualitas kerja perawat.Monitoring yang dilakukan atasan langsung secara berkala juga dapat memacu perawat untuk bekerja lebih baik.Perhatian pimpinan dapat dilakukan dalam bentuk bimbingan dan pengarahan dalam pelaksanaan tugas,ketersediaan waktu atasan untuk mendengarkan saran-saran yang dapat dipertimbangkan, dan sikap terbuka dalam menerima keluhan staf serta mencari bantuan atas permasalahan.

\section{Pengembangan Karier}

Pengembangan karier merupakan salah satu bentuk penghargaan bagi perawat atas kompetensi dan kinerjanya selama bekerja di rumah sakit.Ketika Karier perawat di sebuah rumah sakit tidak berkembang,berarti ada permasalahan serius yang perlu diperhatikan di rumah sakit tersebut.Permasalahan tersebut bisa berasal dari individu yang bersangkutan maupun pihak rumah sakit.Rumah sakit perlu harus mempunyai staf keperawatan yang kompeten sesuai dengan misi,sumber daya,dan kebutuhan pasien.Oleh karena itu,pihak pimpinan atau manajemen rumah sakit harus menjadikan pengembangan karier sebagai salah satu perhatian serius demi kepentingan dan kemajuan bersama.Pengembangan karier perawat dalam bentuk jenjang karier perawat merupakan sistem untuk menggali potensi sesuai dengan bidang pekerjaan melalui peningkatan kompetensi yang menghasilkan kinerja yang professional.

\section{Lingkungan Kerja}

Lingkungan kerja adalah sesuatu yang ada di lingkungan para pekerja yang dapat berpengaruh bagi pekerja di dalam menjalankan setiap tugasnya.Lingkungan kerja dalam arti semua keadaan yang terdapat di sekitar tempat kerja akan mempengaruhi pekerja baik secara langsung maupun tidak langsung.Sehingga lingkungan kerja mampu mempengaruhi kinerja perawat yang diwujudkan dari suatu sikap perawat yang merefleksikan perasaan suka 
terhadap lingkungan yang ada.Dengan lingkungan kerja yang menyenangkan,perawat cenderung akan bekerja dengan sikap disiplin yang tinggi serta semangat dalam bekerja.

\section{Penghargaan}

Penghargaan memiliki pengaruh terhadap kinerja adalah terletak pada kekuatan penghargaan itu sendiri yang sangat efektif sebagai motivator perawat dalam bekerja.Penghargaan meliputi atasan memberikan pujian jika bekerja dengan baik,ide-ide didengarkan dan dipertimbangkan oleh atasan,gaji yang diterima sesuai UMP,menerima insentif tambahan jika pekerjaan melebihi target,saat lembur mendapatkan gaji tambahan,puas dengan penghasilan,peningkatan karir di rumah sakit berjalan sesuai peraturan,selalu dilibatkan dalam acara rumah sakit dan mendapat nilai yang baik dari atasan sehingga perawat bisa meningkatkan kinerjanya.

Kepuasan pasien dipengaruhi oleh banyak faktor,salah satunya ialah kinerja perawat.Kepuasan pasien tidak lepas dari kinerja yang dilakukan perawat dalam menerapkan proses keperawatan.Kinerja perawat yang baik merupakan suatu pelayanan yang dapat memenuhi kebutuhan pasien dan meruppakan indikator terbentuknya kepuasan yang dirasakan oleh pasien,sehingga akhirnya dapat memberikan beberapa manfaat, diantaranya terjadinya hubungan yang harmonis antara petugas kesehatan dan pasien.

Salah satu proses keperawatan ialah pengkajian.Pengkajian keperawatan adalah tindakan yang digunakan perawat untuk mengukur keadaan pasien.Kegiatan yang dilakukan dalam pengkajian adalah :

- Pengumpulan data

Kegiatan ini merupakan hal yang sangat penting dalam pengkajian.Perawat harus mengumpulkan data yang relevan, akurat, dan lengkap.Data dapat dikumpulkan melalui pasien,keluarga,orang terdekat,dan rekam medik.

- Pengkajian on going

Pengkajian ini adalah pengkajian untuk mengkonfirmasi dan perluasan data dasar.

- Pengkajian khusus

Pengkajian dilakukan apabila pasien membutuhkan pengkajian dengan menggunakan alat ukur khusus.

- Validasi data

1. Mengidentifikasi data yang telah dikumpulkan dengan nilai standar dan nilai normal yang lazim digunakan untuk menentukan nilai-nilai abnormal klien 
2. Data subjektif divalidasi dengan data objektif

3. Bandingkan data subjektif dan objektif pasien dengan nilai standar normal yang lazim dipakai

Kemampuan yang harus dimiliki perawat dalam pengkajian

a. Kemampuan komunikasi terapeutik

Komunikasi yang sopan,ramah,dan penuh empati akan sangat membantu dalam menjalin hubungan antara klien-perawat.Hubungan yang baik dapat meningkatkan hubungan saling percaya sehingga dalam melakukan pengkajian,perawat akan mendapatkan data yang relevan dan valid

b. Memiliki pengetahuan

Pengetahuan yang dimiliki perawat sangat penting untuk meningkatkan kemampuan wawancara perawat terhadap klien.

c. Kemampuan melakukan observasi

Kemampuan observasi adalah kemampuan mengamati,mendengarkan,membau dan merasakan,dalam hal ini perawat harus mampu mengandalkan sensitivitas panca inderanya.Perawat harus memahami dan peka terhadap penurunan maupun perbaikan kondisi yang dialami klien sehingga perawat dapat menentukan tindakan yang tepat.

d. Kemampuan melakukan pemeriksaan fisik

Pemeriksaan fisik head to toe merupakan salah satu sarana untuk dapat menentukan abnormalitas fungsi organ tubuh pasien yang perawat kaji.

Beberapa kemampuan tersebut juga dapat termasuk faktor yang berhubungan dengan kinerja perawat dalam penerapan proses keperawatan.Sehingga kemampuan tersebut dapat dilatih agar pelaksanaan proses keperawatan dapat dilakukan dengan baik.

\section{Penutup}

Kesimpulan

Kinerja perawat sebagai ujung tombak pelayanan kesehatan merupakan masalah yang sangat penting dalam rangka penerapan proses keperawatan.Maka,perawat yang memiliki kinerja yang baik dan menerapkan proses keperawatan dengan benar sesuai standar dapat menjamin kepuasan pasien terhadap pelayanan kesehatan.

Saran

Diharapkan pelayanan kesehatan memperhatikan faktor yang berhubungan dengan kinerja perawat dalam penerapan proses keperawatan agar terlaksana dengan baik.Pihak pelayanan kesehatan dapat menciptakan kinerja perawat yang baik apabila pelayanan kesehatan 
memberikan penghargaan pada perawat yang mendapat penilaian terbaik berdasarkan tindakannya.

\section{Daftar Pustaka}

Ayu Shinta Arini.2016.Hubungan Kinerja Perawat Pelaksana Dengan Tingkat Kepuasan Pasien Di Ruang Rawat Inap Penyakit Dalam RS Pertamina Bintang Amin Bandar Lampung Tahun 2016.Jurnal Kesehatan Holistik, 10 (4), 19-23.

Desrison dan Sri Langgeng Ratnasari.2018.Kinerja Perawat Di Instalasi Rawat Inap RSUD Sawahlunto.Jurnal BENING, 5 (2), 91-106.

Gunawan,Tri Anjaswarni,dan Sarimun.2017.Hubungan Antara Pengetahuan Dengan Kinerja Perawat Dalam Melaksanakan Asuhan Keperawatan Di Ruang Rawat Inap Rumah Sakit Tingkat II dr.Soepraoen Malang.Nursing News, 2 (2), 195-205.

Hafid Muh.Anwar.2014.Hubungan Kinerja Perawat Terhadap Tingkat Kepuasan Pasien Pengguna Yankestis Dalam Pelayanan Keperawatan Di RSUD Syech Yusuf Kab.Gowa.Jurnal Kesehatan, 7 (2), 368-375.

Khamida dan Mastiah.2015.Kinerja Perawat Dalam Memberikan Asuhan Keperawatan Berpengaruh Terhadap Kepuasan Pasien Rawat Inap.Jurnal Ilmiah Kesehatan, 8 (2), 154-161.

Mandagi Fergie M.,dkk.2015.Analisis Faktor-Faktor yang Berhubungan Dengan Kinerja Perawat Dalam Menerapkan Asuhan Keperawatan Di Rumah Sakit Umum Bethesda GMIM Tomohon.Jurnal e-Biomedik, 3 (3), 884-894.

Oxyandi Miming.2018.Kinerja Dan Lingkungan Kerja Perawat Pelaksana Dalam Melaksanakan Asuhan Keperawatan.Jurnal Ilmiah Multi Science Kesehatan, 9 (3), 316-332.

Ratanto.2013.Pengembangan Karir $=$ Faktor Paling Mempengaruhi Kinerja Perawat Pelaksana.Jurnal Husada Mahakum, 3 (5), 253-262.

Sabarulin,Darmawansyah,dan Rasyidin Abdullah.2013.Faktor Yang Mempengaruhi Kinerja Perawat Dalam Mendokumentasikan Asuhan Keperawatan Di Rumah Sakit Woodward Palu.Jurnal AKK, 2 (3), 29-34.

Simamora, R. H. (2019). Development of Guidelines for Applying appropriate Patient Identification to Achieve Patient Safety Goal 
INC2019 12th International Nursing Conference. 2019.10455 - 455 (1 pages) UCI(KEPA) : I410-ECN0101-2019-512-001224337

Simamora. R. H. (2008) The correlation of ward chief's giving direction and command and the performance of on-duty nurses at Jember dr. Subandi general hospital inpatient wards. jurnal Administrasi dan Kebijakan Kesehatan, (https://fkm.unair.ac.id/jurnal-administr)

Terok Maria,Hans Sumarauw,dan Stevany Lidya Onseng.2015.Hubungan Kinerja Perawat Pelaksana Dengan Penerapan Proses Keperawatan Di Irina C Blu RSUP Prof Dr.R.D.Kandou Manado.JUIPERDO, 4 (1), 55-60.

Wayan Sudarto.I.,Edi Dharmana,dan Agus Santoso.2014.Pengaruh Loyalitas Dan Kepuasan Terhadap Kinerja Perawat Dalam Asuhan Keperawatan Pasien Rawat Inap Rumah Sakit Swasta Di Yogyakarta.Jurnal Managemen Keperawatan, 2 (1), 22-29.

Yanti Retyaningsih Ida dan Bambang Edi Warsito.2013.Hubungan Karakteristik Perawat,Motivasi,dan Supervisi Dengan Kualitas Dokumentasi Proses Asuhan Keperawatan.Jurnal Managemen Keperawatan, 1 (2), 107-114. 